\title{
Exploring Troubles, Attitudes, and Strategies Related to Integrated Aquaculture. A Case of the Andalusia Region (South of Spain)
}

\author{
Marianna Cavallo ${ }^{1, *(D)}$, Katia Frangoudes ${ }^{1}$, José Pérez Agúndez ${ }^{2}$ and Pascal Raux ${ }^{1}$ \\ 1 University of Brest, Ifremer, CNRS, UMR 6308, AMURE, IUEM, 29280 Plouzane, France; \\ katia.frangoudes@univ-brest.fr (K.F.); Pascal.Raux@univ-brest.fr (P.R.) \\ 2 Ifremer, Univ Brest, CNRS, UMR 6308, AMURE, Unité d'Economie Maritime, IUEM, \\ F-29280 Plouzane, France; jose.perez@ifremer.fr \\ * Correspondence: Marianna.Cavallo@univ-brest.fr; Tel.: +33-02-90-91-56-14
}

Received: 29 July 2020; Accepted: 28 August 2020; Published: 4 September 2020

\begin{abstract}
With the adoption of the Maritime Spatial Planning, European countries have recognized the need to move towards multi-sectoral management of marine resources and space. The present study discusses the problems and opportunities associated with an integrated aquaculture development along the coast of Andalusia through an in-depth analysis of legislative documents and face-to-face interviews. The findings suggest that the management of the aquaculture sector has been characterized by a sectoral approach with little integration into the existing economic activities and socio-cultural context leading to conflicts among fisheries and lack of acceptance from local communities. During the last decade, the regional competent authority and the aquaculture sector implemented several strategies to improve the integration with the other coastal users and enhance the social acceptability of this activity in the area.
\end{abstract}

Keywords: integrated marine management; aquaculture management; marine spatial planning; blue economy

\section{Introduction}

The development and expansion of new maritime activities are expected to have an impact on existing social, cultural, and economic dynamics of local communities where they occur. While the assessment of the impact of human activities has been traditionally focused on the physical and biological alteration of the environment, the adoption of the ecosystem-based approach encompasses the connectivity of all elements of an ecosystem, including humans [1]. With the adoption of the Integrated Maritime Policy, European countries recognized that the sectoral management of marine resources is no longer appropriate: "all matters relating to Europe's oceans and seas are interlinked, and that sea-related policies must develop in a joined-up way if we are to reap the desired results" [2]. The Maritime Spatial Planning Directive (MSPD, 2014/89/EU) is one of the pillars of this policy requiring Member States to establish plans to integrate the maritime dimension of coastal activities and their impacts and ultimately allow an integrated and strategic vision (paragraph 16, MSPD). Ecosystem services often interact with one another generating tradeoffs that may be mutually exclusive in space [3], e.g., aquaculture sites may preclude commercial fishing and vice versa.

Aquaculture is regulated by a number of legal frameworks at international, national, and local scales and, at the European level, there are more than 300 rules that affect this industry [4]. Multiannual National Strategic Plans with specific objectives for aquaculture development have to be implemented by each European Member States to meet the requirements of the Common Fishery Policy (CFP, 
Regulation (EU) No 1380/2013 as amended) accompanied by Operational Programmes supported by the European Maritime and Fisheries Fund (EMFF).

In the development and implementation of an aquaculture project, the economic derived benefits and the environmental impacts are usually clearly defined, while less attention is given to the social and economic impact on the communities. Such a lack of consideration of local communities' needs increases the risk of conflicts and reduces the chances of success [5]. The reactions of local communities to an aquaculture project are difficult to predict and will largely depend on the perception they have toward the activity as well as their relationship with the sea [4]. For instance, fishers will be the first to notice the assault to the fishing ground; leisure activities will be concerned about the impact on their environment while the tourism sector will try to prevent any economic loss deriving from the industrialization of the sea, especially if it is visible [4].

The conflicts that may derive from aquaculture development with other maritime sectors but also with coastal communities have been largely ignored in the past [6-8]. In Asia, for example, the rapid conversion of portions of land and sea to industrial shrimp farming led to confrontations among marine users [9-11]. In Canada, the rapid development of salmon farming located close to traditional lobster fishing areas generated opposition from local fishers concerned about the long-term effects on marine environmental quality [12].

The academics and policy-makers are still debating on how to promote effective integrated management of multi-scalar and cross-sectoral governance across coastal systems [13]. Even though there is not a universally recognized definition of integrated coastal management, this is described as a process "for the sustainable management and use of coastal zones, taking into account at the same time the fragility of coastal ecosystems and landscapes, the diversity of activities and uses, their interactions, the maritime orientation of certain activities and uses and their impact on both the marine and land parts" [14] and a framework that "requires the active and ongoing involvement of the interested public and the many sectoral groups in how resources are allocated, development options are negotiated and conflicts mediated" [15].

The present study wants to contribute to the existing literature to understand how aquaculture interacts, or interferes, with the existing socio-cultural context and economic activities. The area selected is the Andalusia region (South of Spain) which hosts a wide range of maritime activities. The first step is the identification of the elements hampering aquaculture development, followed by issues that generate conflict and strategies adopted to improve the acceptance of the activity by local communities.

\section{Study Area}

The Spanish aquaculture and coastal fishing sector follow a federal-like approach under the exclusive management of the autonomous regions. The fishery sector is traditionally organized in Fishers Guilds ("Cofradias") as socio and economic associations which play a key role in the control of the fishing rights while the "lonjas" are commercial fleet homeports where catches are sold [16].

All Spanish regions published a specific strategic national plan for aquaculture for the period 2014-2020 to meet the requirement of the Common Fishery Policy and related national and regional legislation [16].

The present study focuses on the analysis of the aquaculture sector of the Andalusia region and the way it interacts with the other coastal activities. This region contributes to $12 \%$ of national production in terms of volume and 3\% in terms of value representing the 4th most important producer after Galicia, Valencia, and Murcia regions [17]. The regional aquaculture plan identified several threats and weaknesses hampering the affirmation and further development of the sector and a number of actions are proposed for the period 2014-2020 to increase the production while ensuring the environmental and social sustainability. The regional competent authority, hereafter the AGAPA (Andalusian Agricultural and Fisheries Management Agency), advanced three scenarios of production for the period 2012-2020 with an increase of $45 \%$ and $62 \%$ for the stable and best-case scenarios respectively [18]. Nonetheless, according to the last data (see [19]), the volume of production of 2018 was very close to 2012 (7687 t) 
reflecting the worst-case scenario. Among the weaknesses of the sector, the Region identified the bad image of the products, the negative environmental impacts, and the lack of space leading to competition with other users [18].

The Andalusian coastline, and in particular the "Costa del Sol", represents one of the most popular tourist destinations in the entire Mediterranean Sea hosting a wide range of activities strictly dependent on the good quality of marine water and the landscape. Fisheries, in particular, are considered the most relevant traditional and cultural coastal activity contributing to the local food provision and are an added value for tourism. The area of the present study, the Malaga province, includes four fishery Cofradias: Estepona, Marbella, Fuengirola, and Caleta de Velez (Figure 1). Here, fisheries, marine tourism, and aquaculture share the use of the coastal waters and port facilities but, while fisheries and tourism have coexisted in the area since the first decade of the XX century [20], aquaculture is more recent and it is struggling to be integrated into the existing social, economic and institutional context [18].

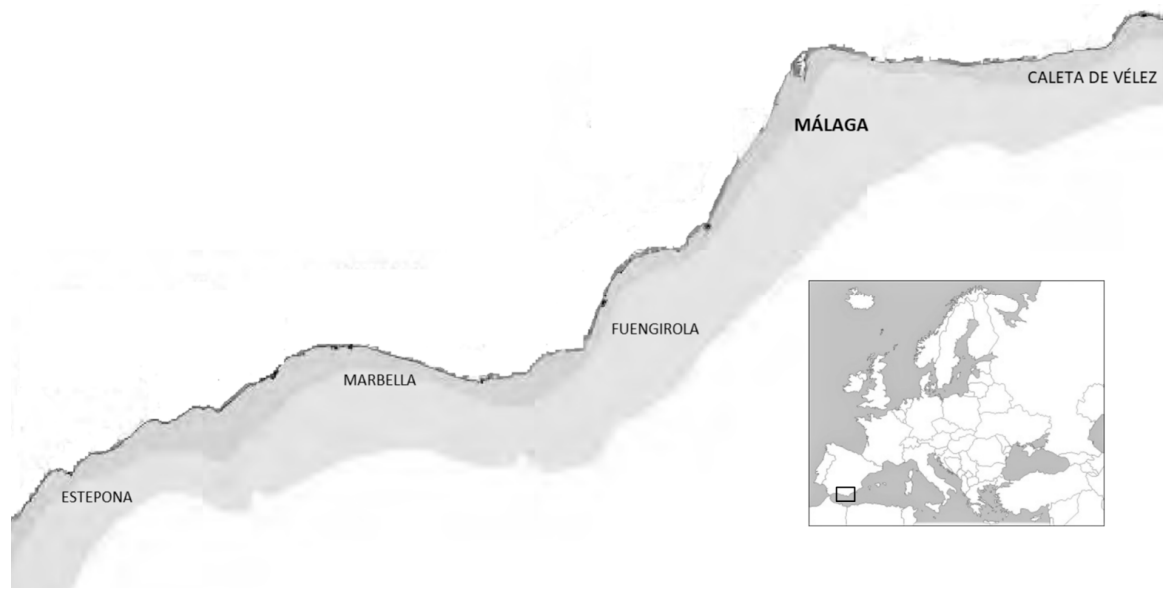

Figure 1. Map of the four Malaga Cofradias.

\section{Methodology}

The first step of the study consisted of an in-depth analysis of the national, regional, and local documents concerning fishery and aquaculture development in Spain and along the Malaga coast (Table 1). The analysis allowed the identification of the threats and weaknesses of local aquaculture and, most importantly, the interaction with the other activities and the management strategies proposed to prevent conflicts in the future.

Table 1. List of international, national, regional, and local documents analyzed (Acronyms: AZAs: Allocated zones for Aquaculture).

\begin{tabular}{cll}
\hline \multicolumn{1}{c}{ Institution } & \multicolumn{1}{c}{ Type of Information } & \multicolumn{1}{c}{ Literature } \\
\hline \multirow{2}{*}{ FAO } & Guide for the establishment of the AZAs & Macias et al., 2019 [21] \\
& Public Understanding and Acceptance of Aquaculture & FAO. 2016 [22] \\
European Commission & Spanish Maritime Spatial Planning & EC, 2018 [23] \\
Spanish Government & National Strategic Plan for Aquaculture & PEP, 2015 [17] \\
& Operational Programme & PO FEMP, 2015 [24] \\
& Regional Strategic Plan for Aquaculture & AGAPA, 2012 [18] \\
AGAPA & Maps of AZAs & AGAPA, 2014 [25] \\
& Statistics of aquaculture production & AGAPA, 2019a [19] \\
GDP Malaga & Local Strategic Development of Fishery & GAP-Malaga, 2014 [26] \\
\hline
\end{tabular}

The second step was to complement this analysis with face-to-face interviews. Semi-structured interviews were carried out in the period 2017-2019 throughout the region to actors directly or indirectly related to aquaculture development (Table 2). Interviewees from the aquaculture (3), fishery 
(19), and tourism (2) sectors include both single businesses and representatives of each category (i.e., aquaculture producer organizations). Among fishers, all types of gears from the four Cofradias took part in the survey, including recreational fishery and fishery-related jobs. Representatives of the administrations include staff from the AGAPA agency at regional (3) and local (1) level, port authority (1), and Ministry of Environment (1). The interviews with the research institutions (3) were necessary to include experts' views of the local fishery and aquaculture context. The first round of questions was addressed to all stakeholders to identify the main constraints hampering aquaculture growth and to explore the society opinion towards this activity, while a specific set of questions was addressed to the fishery, aquaculture and tourism sectors to understand their relationship and the way they interact at sea and at port.

Table 2. The main issues explored in the semi-structure interview and categories of participants.

\begin{tabular}{|c|c|c|}
\hline Issue & Category of Questions & Category of Interviewee \\
\hline \multirow[t]{5}{*}{ Governance } & $\begin{array}{l}\text { Institutions and regulations managing } \\
\text { the sector in the region }\end{array}$ & $\begin{array}{l}\text { Administration, aquaculture, } \\
\text { research institution }\end{array}$ \\
\hline & Criteria used to select aquaculture sites & $\begin{array}{l}\text { Administration, aquaculture, } \\
\text { research institution }\end{array}$ \\
\hline & $\begin{array}{l}\text { Strategies of local consultation in } \\
\text { aquaculture management }\end{array}$ & All categories \\
\hline & $\begin{array}{l}\text { Mistakes made in the past in } \\
\text { aquaculture management }\end{array}$ & All categories \\
\hline & Strategies and objectives for the future & $\begin{array}{l}\text { Administration, aquaculture, } \\
\text { research institution }\end{array}$ \\
\hline \multirow[t]{3}{*}{ Socio-economic } & $\begin{array}{l}\text { Relationship of the interviewees with } \\
\text { the aquaculture sector }\end{array}$ & All categories \\
\hline & Local public perception of aquaculture & All categories \\
\hline & $\begin{array}{l}\text { Level of involvement in the } \\
\text { decision-making of the fishery and } \\
\text { aquaculture related measures }\end{array}$ & Fisheries \\
\hline \multirow[t]{4}{*}{ All issues } & $\begin{array}{l}\text { Main constraints of aquaculture } \\
\text { development in the region }\end{array}$ & All categories \\
\hline & Problems faced by the fishery sector & $\begin{array}{l}\text { Fisheries, aquaculture, administration, } \\
\text { research institution }\end{array}$ \\
\hline & Interaction among activities in the area & All categories \\
\hline & Interaction with the aquaculture sector & $\begin{array}{l}\text { Fisheries, tourism, administration, } \\
\text { research institution }\end{array}$ \\
\hline
\end{tabular}

The last step was an analysis of the proposed actions to overcome the problems in the future. In particular, the strategies related to the marine spatial planning were considered taking into account the information provided in the official documents and the outcome of dedicated workshops organized by the AGAPA in 2019.

\section{Results}

\subsection{Constraints of Aquaculture Development}

The answers provided by all categories of interviewees suggest that there are social, economic, environmental, and governance issues that are preventing or have prevented in the past, the consolidation, and the expansion of local aquaculture (Table 3). For instance, unsuitable environmental conditions, such as the presence of toxins, cause animal mortality but also economic loss when the products do not meet safety consumption standards. 
Table 3. Elements hampering aquaculture development of Andalusia according to the interviews (in brackets the category of respondent).

\begin{tabular}{|c|c|}
\hline Issue & Answers \\
\hline \multirow{4}{*}{ Social } & $\begin{array}{l}\text { Negative interaction with fisheries, tourism, and local residents (administration, } \\
\text { aquaculture, research institution, tourism, fisheries) }\end{array}$ \\
\hline & $\begin{array}{l}\text { Increasing conflicts derived from the lack of space in port and at sea } \\
\text { (administration) }\end{array}$ \\
\hline & $\begin{array}{l}\text { Social concerns over the environmental impact (research institution, aquaculture, } \\
\text { administration, fisheries) }\end{array}$ \\
\hline & $\begin{array}{l}\text { Aquaculture products suffer from bad image by consumers in Spain and Andalusia } \\
\text { (research institution, aquaculture, administration) }\end{array}$ \\
\hline \multirow{8}{*}{ Economic } & $\begin{array}{l}\text { Higher costs/taxes for producers respect to other Spanish regions } \\
\text { (research institution) }\end{array}$ \\
\hline & Lack of suitable insurances (research institution) \\
\hline & Lack of infrastructures, e.g., roads, bivalve depuration facility (aquaculture) \\
\hline & Lack of dedicated funding (aquaculture) \\
\hline & $\begin{array}{l}\text { High competition in the market with other EU and non-EU Mediterranean } \\
\text { countries (aquaculture, administration) }\end{array}$ \\
\hline & Economic loss resulting from land-based contamination (administration); \\
\hline & Speculation of big business at the expenses of the smaller (research institution) \\
\hline & Low profitability of the sector (fisheries) \\
\hline \multirow{3}{*}{ Environmental } & Lack of seeds (administration) \\
\hline & $\begin{array}{l}\text { Unsuitable environmental conditions: temperature, strong currents/wave } \\
\text { exposition (research institution, administration); }\end{array}$ \\
\hline & IMTA * is not possible because includes invasive species (research institution) \\
\hline \multirow{3}{*}{ Governance } & $\begin{array}{l}\text { Complex and long licensing procedure/legislative framework (administration, } \\
\text { research institution, aquaculture) }\end{array}$ \\
\hline & $\begin{array}{l}\text { Lack of coordination between local and regional authorities in the aquaculture site } \\
\text { section in the past (administration) }\end{array}$ \\
\hline & Lack of institutional support from the regional agency in the past (aquaculture) \\
\hline
\end{tabular}

${ }^{*}$ IMTA: Integrated multi-trophic aquaculture.

The first seabass and seabream farms in the area appeared in the 90s and were gradually replaced by shellfish farming (mussels and scallops) that now represents the 100\% of the production with 13 enterprises that moved from the north of Spain (Galicia) where this activity is more established (administration). According to one representative of the AGAPA and the aquaculture association, despite being in the area for 30 years, aquaculture is still considered a new activity in a region dominated by tourism and traditional fishery and it is struggling to integrate into the existing socio-economic context.

The limited port infrastructures (e.g., mooring and storing capacity) and the tight continental shelf have hampered the growth of the sector and, according to some answers, this lack of space will be one of the main limitations for the expansion of the sector in the future (aquaculture producer association, fishers, and fishery representatives, port authority). In the scenario of an increase of production of $30-40 \%$, as estimated by the regional competent authority in the strategic plan, competition for space with other sectors and concerns over the environmental degradation resulting from certain types of aquaculture could lead to social opposition to aquaculture projects (fishers). According to a representative of the farmers' association, such concerns are based on misconceptions about aquaculture environmental impact. For some fishers, however, some mistakes were made in the past by certain producers and the competent authorities failed to guarantee compliance with environmental regulation. When asked about the perception of aquaculture products in the region and Spain in general, the representative of a producers' association affirms that the image of farmed seafood has improved considerably as a result of the promotion initiatives carried out by the sector throughout all the value chain, starting from the large retailers to restaurants. The sector has worked with the support of the regional administration to promote the quality and the safety of aquaculture products, i.e., the day of aquaculture, dedicated workshops, training of press. Nonetheless, "while the consumption 
of shellfish aquaculture (i.e., mussels and oyster) is widely accepted, there is still a general preference to consume wild fish instead of farmed one" (producer).

Other aspects are related to the economic profitability of the sector. In fact, in Andalusia, the higher investment required to start an aquaculture project with respect to the other regions (e.g., Galicia) forces producers to increase the price of the products which cannot compete with the other Spanish regions, Greece and North Africa markets (regional administration). Some fishers doubt about the economic profitability of aquaculture given the failed attempts of the past along the coast: "the first sites that produced finfish were dismissed after a few years and moved somewhere else and shellfish business are following the same fate (... )"; "some enterprises moved from the north of Spain due to the lack of space but they did not find the suitable environmental conditions here and they are struggling to consolidate their business that largely depends on public subsidies".

According to some fishers and aquaculture producers, another problem hampering the affirmation of the sector in the Malaga coastline is related to the land-based contamination determined by more than 100 untreated sewage outputs that make aquaculture products not suitable for the market (toxins and heavy metals).

Governance related aspects seem to be the most relevant problem for aquaculture producers. The complexity and timelines associated with administrative and licensing processes to gain permission for aquaculture activity have been identified by four interviewees as one of the main factors preventing the sector growth. According to the representative of producers, a simplification of the EU legislation is necessary to avoid overlapping and unnecessary requirements while ensuring the good status of the surrounding environment, animal wellbeing, and high food quality.

When asked about (mis)management strategies adopted in the past, the lack of consultation and coordination between the regional administration and the local authorities (e.g., port administration and city councils) in the aquaculture site selection determined competition with existing users. One (aquaculture) producer said that some of the past failed attempts were determined by the lack of consultation of producers in the process of site selection. The regional administration admits that mistakes were made in the past and says that they have learned from those bad experiences and now local administrations and businesses are consulted and an ad-hoc platform has been created to include all interested parties from the early stages of aquaculture planning.

\subsection{Interaction among Activities}

The interaction, positive and negative among the three major activities, and the local communities have been further explored with ad-hoc questions to understand how and where they overlap along the Malaga coast, which were the mistakes made in the past and the current perception (Table 4).

Among the activities that occur along the Malaga coast, a rather complex interaction has been observed between fisheries and aquaculture which seems quite affected by the way this last one has been managed in the past. Among fishers, there is disappointment about the fact that when aquaculture was first developed "they (the producers) said they would have hired young fishers but they never did, they rather employed people from the north of Spain (Galicia) where the business came from". Moreover, a fisher describes an accident that happened with a farm site as a result of the lack of visibility while other fishers insist on the fact that aquaculture sites both increase the time and money expenses to find an alternative route in case of strong current as their gear can hit the aquaculture sites, which poses a safety problem. In the last years, some enterprises have been dismissed but they left part of the equipment on the sea bottom preventing them (the fishers) to fish. Others have abandoned some facilities on the port causing smell and occupying valuable space, e.g., Marbella. 
Table 4. Type of interactions among the three maritime sectors and with local community identified by interviewees (in brackets the category of interviewees).

\begin{tabular}{|c|c|c|c|}
\hline Sectors & Positive & Negative & Little/No Interaction \\
\hline Aquaculture vs. fisheries & $\begin{array}{l}\text { Aquaculture provides alternative } \\
\text { jobs opportunities for local fisheries } \\
\text { (fisheries, aquaculture) }\end{array}$ & $\begin{array}{l}\text { Unattended commitment to hiring local fishers in } \\
\text { the past (fisheries) } \\
\text { No contribution to the fishery Cofradia as the } \\
\text { products are not sold at the "lonja" (fisheries) } \\
\text { Conflict may rise when aquaculture sites are placed } \\
\text { in fishing areas (administration, research institution, } \\
\text { fisheries, tourism) } \\
\text { Competition for the use of port facilities and space, } \\
\text { e.g., stockrooms (administration, fisheries) } \\
\text { Competition for access to subsides (fisheries) } \\
\text { Lack of involvement of the fishing sector in the site } \\
\text { selection (fisheries) } \\
\text { Deterioration of environmental quality resulting } \\
\text { from aquaculture practices has a negative impact on } \\
\text { fishery (fisheries) } \\
\text { Indirect competition in the market for the products } \\
\text { (fisheries); }\end{array}$ & $\begin{array}{l}\text { Little direct competition in the market } \\
\text { for the products (fisheries, aquaculture, } \\
\text { administration); } \\
\text { Little negative interaction of current } \\
\text { aquaculture sites with fishery (fisheries) }\end{array}$ \\
\hline Aquaculture vs. tourism & $\begin{array}{l}\text { Aquaculture and tourism benefit } \\
\text { each other (tourism, aquaculture) }\end{array}$ & $\begin{array}{l}\text { Seaview from bars and restaurants on the beach } \\
\text { might be negatively affected by aquaculture sites } \\
\text { (administration) } \\
\text { Competition with nautical tourism for the use of } \\
\text { port facilities and sea space, e.g., Marbella } \\
\text { (administration) }\end{array}$ & \\
\hline $\begin{array}{l}\text { Aquaculture vs. local } \\
\text { communities }\end{array}$ & & $\begin{array}{l}\text { Occasional opposition of local residents and } \\
\text { administrations to aquaculture development } \\
\text { (administration, aquaculture, research institution) } \\
\text { Occasional opposition of environmental NGOs } \\
\text { concerned for the environmental impact } \\
\text { (research institution) }\end{array}$ & $\begin{array}{l}\text { Aquaculture has very little impact and } \\
\text { provides some ecosystem services } \\
\text { (administration, research institution) }\end{array}$ \\
\hline
\end{tabular}


Because of the current limited aquaculture development, all but 3 fishers affirm that there is very little interaction with the current aquaculture sites and that "they do not have any major problem since the two activities are not connected although they share the same space".

Nonetheless, when asked about the future of aquaculture in the area, almost all fishers believe that having in mind the failure of past attempts, further development will not be possible as a result of the unsuitable environmental, ecological and hydrographic conditions, the little economic profitability and the low price of products. Moreover, interviewees from all categories agree that a significant increase of aquaculture sites, like the one estimated by the regional authority, will lead to conflicts with fishers if new sites overlap the already limited fishery areas. The responses varied according to the category of fishers; for example, the trawlers and purse seine fishers are less impacted by aquaculture since their fishery area is located away from the coast and they have the capability to extend their fisheries ground to avoid aquaculture. On the other hand, small scale fishers are the most impacted since the current sites are located on their fishing ground and they have a limited capacity to move somewhere else. Different views were also observed among types of fishing gear about the future opportunities offered by local aquaculture, where two small-scale fishers say they might consider moving to the aquaculture sector as they believe that artisanal fisheries are declining and they are not able to make a living from it.

Other reasons for conflicts were related to the fact that some small-scale fishers have experienced an increasing reduction of subsidies to buy new appliances to fix their boat or to start a new activity while big trawlers and aquaculture have easier access to such funds. Moreover, the lack of involvement in the aquaculture site selection has undermined trust towards the administration. Currently, single fishers are not directly consulted but representatives ("Patrones Mayor") are responsible to represent their category and negotiate with the regional administration. Finally, some environmental-related issues have been identified in recent years related to aquaculture bad practices. For example, the increased episodes of negative interaction among purse seine fishing and dolphins are believed to be the result of the presence of fish farms in the near province which modified the behavior of this predator that now lives in the area all year and has learned to remove fish from fishing gear decreasing catches and damaging nets.

When asked about the relationship between tourism and aquaculture sectors, both interested parties agree that the two activities are not in conflict but they benefit each other. The Malaga area, they explain, "is particularly known for seafood tradition and aquaculture ensures a continuous provision to local restaurants". A representative of the tourism sector however points out the need to diversify the offer of products and to make them available throughout the year in the market (red tuna, octopus) as well as the possibility to choose the size of farmed products. Nonetheless, respondents from the administration recognize that a rapid expansion of aquaculture in an area strictly dependent on nautical tourism (e.g., Marbella) could lead to conflict when sites are located too close to ports and in case of insufficient mooring space. According to the port authority, because of the crisis of the nautical sector, the demand for mooring from big yachts has decreased in the last years thus there should not be competition with the aquaculture sector in the near future. Two interviewees suggest that better coordination with local administration in the development of aquaculture plans will be useful to identify the real capability of each port and coast length to host new aquaculture projects and thus, prevent conflicts in the future increasing the lack of social acceptability of the sector.

\subsection{Future Strategy for a Better Integration}

According to the information gathered in official documents and the responses provided by interviewees, a number of actions are implemented to overcome the existing technical and socio-economic issues identified as hampering the local aquaculture development.

Interviewees recognize that the aquaculture sector is now receiving adequate institutional support and the AGAPA is working on the development of a single legislative framework specific for aquaculture that regulates aspects such as site selection, licensing, environmental quality requirements, animal welfare, insurance. Moreover, the recent establishment of a Committee for Aquaculture, 
which includes representatives of the administrations at regional and local levels, aquaculture sector and research institutions, is proposed as an important step towards a better institutional coordination and collaboration between the administration and the sector through periodical meeting [18].

The environmental impact of aquaculture has been identified as a threat to other coastal activities and for the acceptability of farmed products in analyzed documents but also the interviews. For example, an aquaculture representative has recognized this as a major problem and they (the sector) are looking at alternatives farming systems, such as offshore sites, IMTA (Integrated multi-trophic aquaculture), and diversification of species. Ecological impacts are also observed by certain fishing gears. In fact, purse seine fishers are experiencing growing negative interaction with dolphins (damage to the net and depredation of fish) and some of them believe that the nearby fish farm has modified the behavior of these mammals. A research institution in collaboration with the Cofradia are working together to understand if there is a correlation between aquaculture and the predator's behavior and eventually adopt mitigation measures.

To improve the image of the farmed products in the market, the AGAPA suggests that producers should work on their promotion strategies (e.g., social media) and new labeling to certify the quality and safety and environmental sustainability of their production systems [18].

Since 2001 [26] the AGAPA has been working on the integration of aquaculture into the local context with the definition of GIS maps of Suitable Sites for Aquaculture in the attempt of finding areas with best environmental conditions and promoting coexistence with other activities. With this strategy, the Region aims to overcome some of the most relevant problems hampering aquaculture growth, namely unsuitable environmental conditions (temperature, strong currents/wave exposition); competition for the use of port facilities and space; negative interaction with fisheries, tourism, and local residents. This site selection process has been recently accompanied by local stakeholders' consultation with the aim of producing more realistic maps that take into consideration how and where aquaculture overlaps with other activities and at which conditions a new project will be compatible with the existing uses. This process is only at the early stages and future multi-stakeholders workshops are foreseen with the local administrations (city councils), tourism sector (nautical, restaurants, hotels, etc.), research institutions, and aquaculture producers (Administration).

\section{Concluding Remarks}

In Spain, there are a number of ongoing sectoral initiatives but there is not yet a defined integrated MSP process [23]. The main purpose of maritime spatial planning is to identify the utilization of maritime space for different sea uses as well as encouraging multi-purpose uses and manage conflicts (Paragraph 19, MSPD).

Andalusian aquaculture occurs mainly on land [18], while in the Malaga province sites are located within around one mile from the coast and the main ports ${ }^{1}$. The choice to allocate aquaculture close to the coast, although convenient for aquaculture producers, has increased the interaction with other sectors and local communities and this study was developed to understand how aquaculture has been integrated into the existing context since its first development. The results of this case study have shown that Andalusian aquaculture in the past was dominated by a sectoral and centralized approach where decisions were taken at the regional level with little coordination with local authorities and lack of understanding of the impact on local communities and the existing activities.

Understanding the socio-cultural and economic context of the area of study was the first step of this study. According to the statistics provided by the AGAPA, the fisheries sector in the province of Malaga has been receding during the last 20 years, reducing the catches by more than half ${ }^{2}$. On the

\footnotetext{
https://servicio.pesca.mapama.es/acuivisor/

2 https://www.juntadeandalucia.es/organismos/agriculturaganaderiapescaydesarrollosostenible/areas/pesca-acuicultura/ comercializacion/paginas/prodpesq2018.html
} 
other hand, the tourism demand ${ }^{3}$ and aquaculture production ${ }^{4}$ have shown a positive trend for the same period. The answers provided indicate that fisheries are an important social and cultural activity in the four ports while tourism is the driving economic activity. Among the elements hampering the growth and consolidation of the aquaculture sector, two types of problems have been identified; (1) sector-related problems, namely unsuitable environmental conditions, lack of infrastructures, complexity and timelines associated with administrative and licensing processes; (2) other problems strictly dependent from the way aquaculture interacts with the other activities and local community, e.g., conflicts with nautical and fishery sectors resulting from the lack of space in ports and at sea, social concerns over the environmental/ecological impact, land-based contamination, etc. This last category of problems has a big social component (other than economic and environmental) that increases the complexity of management and requires a multi-sectoral approach to be prevented and solved. A recent EU funded project, named Aquaspace, analyzing aquaculture strategies of 17 case studies across the world, also came up to the conclusion that conflicts with other users represent the main issue for aquaculture expansion [27]. From the present study, it has emerged that aquaculture and tourism will have mutual benefits from their expansion in the area (e.g., local food provision) while there are indirect consequences for aquaculture resulting from the tourism such us the land-based contamination from unsuitable sewage treatment plants during the high touristic season. In fact, in 2018 the Court of Justice of the European Union ordered Spain to pay a lump sum of 12 million euros for its delay in implementing the Urban Waste Water Treatment Directive in 17 agglomerations ${ }^{5}, 8$ of which are located in Andalusia. As the focus of this study was to investigate the way maritime activities interact at port and at sea, the visual impact of aquaculture sites on the seascape on tourism and local residents has not been investigated and it should be further explored with the dedicated study.

On the other hand, negative interaction among aquaculture and fisheries has been experienced in the past as a result of mismanagement practices (e.g., deterioration of environmental quality resulting from aquaculture) and there is the general feeling among all categories of interviewees that the two activities are not connected although they have been sharing the same space during the last 30 years. Issues like lack of contribution to the local fishery Cofradia, the predominance of external business from other Spanish regions, scarce jobs opportunities, and little consultation of fisheries and their representatives in the past aquaculture development have contributed to isolating the two activities and reduced their capability to interact and benefit each other. The mistakes made in the past have affected the attitude of fishers towards this activity and the trust towards the administration that was responsible to prevent negative impacts on well-established fisheries activities. Both the AGAPA and the aquaculture sector recognize this lack of connection and have been working on building a bridge between aquaculture and society. Nonetheless, strategies are mainly focused on improving the image of aquaculture products among consumers while few actions are proposed to enhance the acceptance of the sector among people living next to aquaculture sites. From the results of this study, it is suggested that some effort might be necessary from producers to connect with local fishers and communities to improve dialogue and trust (e.g., about the environmental impact). The Fisheries Local Action Groups (FLAGs) of Malaga (GDP Malaga) which includes fisheries, aquaculture, and tourism sectors has proposed a Community-Led Local Development strategy for the period 2014-2020. Among the threats and weaknesses identified in this document, there are some issues common to the fisheries and aquaculture sector, namely the land-based contamination with the increase of summer tourism (and consequent closure of fisheries and aquaculture extraction); lack of cooperation among producers/fishers to contrast illegally sold fish; reduction of the fishing/aquaculture areas; growing

3 http://www.juntadeandalucia.es/turismoydeporte/publicaciones/estadisticas/bata_2017.pdf

4 https://www.juntadeandalucia.es/organismos/agriculturaganaderiapescaydesarrollosostenible/servicios/estadisticacartografia/estadisticas-pesqueras/paginas/produccion-pesquera-2018.html

5 https:/curia.europa.eu/jcms/upload/docs/application/pdf/2018-07/cp180120en.pdf 
administrative and legislative complexity; poor recruitment of youth and women; growing competition from third countries and other Spanish regions; growing dependence of both activities from subsidies.

Better integration and cooperation among the three main maritime activities along the coast of Malaga could be of value to overcome some common problems and create new opportunities, e.g., integrate eco-tourism with traditional fisheries and aquaculture, transfer of traditional fisheries knowledge to aquaculture practices, recognize the ecosystem services offered by certain aquaculture that are beneficial for both tourism and fisheries (e.g., nutrient removal), provision of high quality and sustainable food for the local market. External economic support and soft regulatory framework might be required from local and regional administrations to ensure long-term cooperation among local actors as well as political willingness to include multi-sectoral organizations into fisheries and aquaculture management strategies.

Throughout the years, the approach of the competent authority, the AGAPA, has been adapted to improve coordination with local administration and cooperation with producers and local actors in the site selection. For instance, the problems related to the user conflicts were approached with a practical tool offered by the GIS. The main elements taken into consideration in the establishment of aquaculture sites are environmental and hydrological parameters, administrative use, archaeological sites, Site of Community Importance, underwater pipes and marine outfall, golf clubs on the coast, [25] while fishing grounds were poorly included. All the parties interviewed agreed that a further expansion of aquaculture will represent a potential conflict if this overlaps with fisheries and the development of thematic maps where all activities are represented but not truly integrated might not be sufficient to prevent conflicts. Placing certain maritime activities on a map is easier when these are fixed (aquaculture) or when they occur on the surface (shipping/navigation), while the delimitation of fisheries areas is particularly challenging as they cover a vast area, they move according to the season and type of gear, and occur in three dimensions (surface, column, and the bottom of the sea). The AGAPA is now producing GIS maps where fishery grounds are adequately represented and considered in the selection of aquaculture sites and in consultation with local fishers and representatives. During the first consultation meetings, a number of issues were raised by fishers which consider that aquaculture development can undermine the fishing activity by limiting the area of fishing and the availability of port infrastructure, as well as degrade the quality of the environment and potentially compete in the market [28]. At the same time, fishers complained about a lack of transparency in the site selection in the past, lack of financial support to fishers to start aquaculture projects, lack of contribution of aquaculture to the local Cofradia and unattained promises of hiring local young people in the aquaculture and finally the need for the reliable environmental impact assessment of finfish farming [28]. Nonetheless, they also proposed that aquaculture development should first occur in abandoned and not exploited sites and to increase the area of existing sites. Future workshops will be the focus for integrating other coastal actors to gather their opinion and concerns about the future development of aquaculture in the area.

Countries worldwide are facing the growing complexity of ocean management where integrating policy requirements, local planning, and blue economy objectives have become imperative. The marine spatial planning framework offers an opportunity to integrate a wide range of ocean uses instead of being reduced to a zoning instrument, and aquaculture should go beyond the simple spatial allocation of sites $[27,29]$. The findings of this study confirm the need to move towards a bottom-up approach where decisions are taken at the level at which maritime activities occur, taking into account environmental, economic, and social impacts.

Author Contributions: Conceptualization, K.F.; data curation, M.C. and K.F.; formal analysis, M.C.; funding acquisition, J.P.A. and P.R.; methodology, M.C. and J.P.A.; project administration, J.P.A. and P.R.; supervision, K.F. and J.P.A.; validation, K.F., J.P.A. and P.R.; visualization, P.R.; writing-original draft, M.C.; writing-review and editing, M.C. and K.F. All authors have read and agreed to the published version of the manuscript.

Funding: This work is part of the MedAID project that has received funding from the European Union's Horizon 2020 Research and Innovation Programme under grant agreement N. 727315 (http://www.medaid-h2020.eu/). 
Conflicts of Interest: The authors declare no conflict of interest.

\section{References}

1. Long, R.D.; Charles, A.; Stephenson, R.L. Key principles of marine ecosystem-based management. Mar. Policy 2015, 57, 53-60. [CrossRef]

2. COM 575 Final. An Integrated Maritime Policy for the European Union; European Commission: Brussels, Belgium, 2007.

3. Lester, S.E.; Costello, C.; Halpern, B.S.; Gaines, S.D.; White, C.; Barth, J.A. Evaluating tradeoffs among ecosystem services to inform marine spatial planning. Mar. Policy 2013, 38, 80-89. [CrossRef]

4. International Union for Conservation of Nature's (IUCN). Guide for the Sustainable Development of Mediterranean Aquaculture 2. In Aquaculture Site Selection and Site Management; IUCN: Gland, Switzerland; Malaga, Spain, 2009; p. 303.

5. Food and Agriculture Organization (FAO); Fezzardi, D.; Massa., F.; Àvila-Zaragoza, P.; Rad., F.; Yucel-Gier, G.; Deniz, H.; Hadj Ali Salem, M.; Hamza, H.A.; Ben Salem, S. Indicators for sustainable aquaculture in Mediterranean and Black Sea Countries: Guide for the Use of Indicators to Monitor Sustainable Development of Aquaculture. Gen. Fish. Comm. Mediterr. Stud. Rev. 2013, 93, 60.

6. Nash, C.E. Achieving Policy Objectives to Increase the Value of the Seafood Industry in the United States: The Technical Feasibility and Associated Constraints. Food Policy 2004, 29, 621-641. [CrossRef]

7. Mazur, N.A.; Curtis, A.L. Understanding community perceptions of aquaculture: Lessons from Australia. Aquac. Int. 2008, 16, 601-621. [CrossRef]

8. Chu, J.; Anderson, J.L.; Asche, F.; Tudur, L. Stakeholders' perceptions of aquaculture and implications for its future: A comparison of the U.S.A. and Norway. Mar. Resour. Econ. 2010, 25, 61-76. [CrossRef]

9. Martinez-Alier, J. Ecological conflicts and valuation: Mangroves versus shrimps in the late 1990s. Environ. Plan. C Politics Space 2001, 19, 713-728. [CrossRef]

10. Stonich, S.C.; Vandergeest, P. Violence, environment and industry shrimp farming. In Violent Environments; Peluso, N.L., Watts, M., Eds.; Cornell University Press: New York, NY, USA, 2001.

11. Krause, G.; Brugere, C.; Diedrich, A.; Ebeling, M.W.; Ferse, S.C.A.; Mikkelsen, E.; Agúndez, J.A.P.; Stead, S.M.; Stybel, N.; Troell, M. A revolution without people? Closing the people-policy gap in aquaculture development. Aquaculture 2015, 447, 44-55. [CrossRef]

12. Walters, B.B. Competing use of marine space in a modernizing fishery: Salmon farming meets lobster fishing on the Bay of Fundy. Can. Geogr. 2007, 51, 139-159. [CrossRef]

13. Van Assche, K.; Hornidge, A.-K.; Schlüterd, A.; Vaidianuc, N. Governance and the coastal condition: Towards new modes of observation, adaptation and integration. Mar. Policy 2020, 112, 103413. [CrossRef]

14. UNEP/MAP/PAP. Protocol on Integrated Coastal Zone Management in the Mediterranean; Split, Priority Actions Programme: Croatia, 2008; p. 124.

15. GESAMP (IMO/FAO/UNESCO-IOC/WMO/WHO/IAEA/UN/UNEP Joint Group of Experts on the Scientific Aspects of Marine Environmental Protection). The Contributions of Science to Integrated Coastal Management. GESAMP Rep. Stud. 1996, 61, 66.

16. Franquesa, R. The fishers Guilds in Spain (Cofradias): Economic Role and Structural Changes. Environmental Science. IFET Jpn. Proc. 2004, 1-14.

17. PEP. Plan Estratégico Plurianual de la Acuicultura Española 2014-2020; Ministerio de Agricultura, Alimentación y Medio Ambiente-Secretaría General Técnica Centro de Publicaciones; Catálogo de Publicaciones de la Administración General del Estado: Madrid, Spain, 2015; 396p.

18. AGAPA; Andalusian Agricultural and Fisheries Management Agency. Estrategia Andaluza para el Desarrollo de la Acuicultura Marina. 2014-2020; Consejería de Agricultura, Ganadería, Pesca y Desarrollo Sostenible: Sevilla, Spain, 2012; p. 96.

19. AGAPA; Andalusian Agricultural and Fisheries Management Agency. La Acuicultura Marina en Andalucía 2018; Agencia de Gestión Agraria y Pesquera de Andalucía, Consejería deAgricultura, Ganadería, Pesca y Desarrollo Sostenible: Sevilla, Spain, 2019; p. 56.

20. Segreto, L.; Manera, C.; Pohl, M. Europe at the Seaside: The Economic History of Mass Tourism in the Mediterranean; Berghahn Books: New York, NY, USA, 2009. 
21. Macias, J.C.; Avila Zaragozá, P.; Karakassis, I.; Sanchez-Jerez, P.; Massa, F.; Fezzardi, D.; Gier, G.Y.; Franivevi, V.; Borg, J.A.; Perez, R.M.C.; et al. Allocated zones for aquaculture: A guide for the establishment of coastal zones dedicated to aquaculture in the Mediterranean and the Black Sea. GFCM Stud. Rev. 2019, 97, I-84.

22. Food and Agriculture Organization (FAO). Report of the Workshop on Increasing Public Understanding and Acceptance of Aquaculture-The Role of Truth, Transparency and Transformation, Vigo, Spain, 10-11 October 2015; FAO Fisheries and Aquaculture Report No. 1143; FAO: Rome, Italy, 2016.

23. EC. MSP Country Information Profile Spain-December 2018. Available online: https://www.mspplatform.eu/sites/default/files/download/spain_country_information_profile_14.12.2018.pdf (accessed on 17 December 2018).

24. PO FEMP. Programa Operativo. Fondo Europeo per gli Affari Marittimi e la Pesca 2014-2020; Ministero delle Politiche Agricole Alimentari e Forestali: Rome, Italy, 2015; 195p.

25. AGAPA; Andalusian Agricultural and Fisheries Management Agency. Localización de zonas idóneas para desarrollo de la acuicultura marina en Andalucí; Andalusian Agricultural and Fisheries Management Agency: Sevilla, Spain, 2014; p. 21.

26. GAP-Malaga. Estrategia de Desarrollo Local Participativo 2014-2020 para la zona Pesquera de la Provincia de Málaga Grupo de Desarrollo Pesquero de Málaga; Grupo Desarrollo Pesquero de Malaga: Malaga, Spain, 2014.

27. Galparsoro, I.; Murillas, A.; Pinarbasi, K.; Borja, Á.; O’Hagan, A.M.; MacMahon, E.; Gangnery, A.; Corner, R.; Ferreira, J.; Ferreira, R.; et al. Synthesis of the Lessons Learned from the Development and Testing of Innovative Tools to Support Ecosystem-Based Spatial Planning to Aquaculture, Deliverable 5.1; AquaSpace: Ecosystem Approach to Making Space for Aquaculture; EU Horizon 2020 Project Grant No. 633476. 2017; 103.

28. AGAPA. Andalusian Agricultural and Fisheries Management Agency. Acta de reunion 22 de Junio 2019. In Proceedings of the Taller con Patrones Mayores y Representantes de las Distintas Modalidades de Pesca de la Provincia de Málaga, Celebrado en el Ambito del Proceso de Concertación para la Declaración de Zonas de Interés para el Desarrollo de la Acuicultura en la Provincia de, Málaga, Sevilla, Spain, June 2019; p. 8, unpublished.

29. Cavallo, M.; Pérez-Agúndez, J.; Raux, P.; Frangoudes, K. Is existing legislation supporting socially acceptable aquaculture in the European Union? A transversal analysis of the north-western Mediterranean region. Rev. Aquac.. under review.

(C) 2020 by the authors. Licensee MDPI, Basel, Switzerland. This article is an open access article distributed under the terms and conditions of the Creative Commons Attribution (CC BY) license (http://creativecommons.org/licenses/by/4.0/). 